\title{
CURRENT DEBATES IN URBAN THEORY: A CRITICAL ASSESSMENT
}

\author{
Michael Storper, \\ Distinguished Professor of Regional and International Development, UCLA; \\ Professor of Economic Geography, London School of Economics; \\ Professor of Economic Sociology, Sciences Po Paris, \\ and \\ Allen J. Scott, \\ Distinguished Research Professor, \\ UCLA.
}

We dedicate this paper to our late friend and colleague Edward Soja in the full knowledge that he would have been unable to resist expressing alternative perspectives on almost everything we say. 


\begin{abstract}
$\underline{\text { Abstract }}$
Urban studies today is marked by many active debates. In an earlier paper, we addressed some of these debates by proposing a foundational concept of urbanization and urban form as a way of identifying a common language for urban research. In the present paper we provide a brief recapitulation of that framework. We then use this preliminary material as background to a critique of three currently influential versions of urban analysis, namely, postcolonial urban theory, assemblage theoretic approaches, and planetary urbanism. We evaluate each of these versions in turn and find them seriously wanting as statements about urban realities. We criticize (a) postcolonial urban theory for its particularism and its insistence on the provincialization of knowledge, (b) assemblage theoretic approaches for their indeterminacy and eclecticism, and (c) planetary urbanism for its radical devaluation of the forces of agglomeration and nodality in urban-economic geography.
\end{abstract}




\section{Urban Challenges and Urban Theory in the 21st Century}

The current period of human history can plausibly be identified not only as a global but also as an urban era. This is a period in which population, productive activity, and wealth are highly and increasingly concentrated in cities. ${ }^{1}$ Most cities offer a better standard of living for more people than ever before in human history; even the urban poor are better off, on average, than the rural poor around the world. Cities are primary centers of scientific, cultural and social innovation (Hall, 1998; Glaeser, 2012). Cities have also proliferated all over the globe and have become increasingly interdependent so that where once we could speak quite meaningfully of "national urban systems" (most extensively developed in the Global North) the current situation is one marked by an increasingly integrated world-wide network of cities together with an extraordinary surge of urban growth in the Global South (McKinsey, 2011). But this era is also in some ways a dark age as marked by gutted-out old industrial cities, concentrated poverty, slums, ethnic conflict, ecological challenges, unequal access to housing, gentrification, homelessness, social isolation, violence and crime, and many other problems. There has been a corresponding proliferation of academic and policy-related research on cities and a vigorous revival of debates about the content and theoretical orientation of urban studies.

In this paper we discuss three currently influential perspectives on these debates, namely, postcolonial urban analysis, assemblage theoretic accounts of the city, and the theory of "planetary urbanism." In their different ways, each of these three bodies of work attempts to provide bold understandings of the empirical trends referred to above. At the same time, each of them seeks to present an account of the city that poses strong challenges to much if not most hitherto existing urban theory As such, these perspectives are prominent expressions of a renewed vibrancy and innovativeness in urban studies reflecting the dramatically shifting geographies of urbanization noted above - but in ways

${ }^{1}$ In this paper, the term "cities" will generally be used to cover both small and large urban forms, including metropolitan areas and city-regions. 
, as we shall argue, that often appear to be highly problematical. It should be stressed, at the outset, that these three bodies of work have different points of intellectual origin and different points of emphasis, though postcolonial and assemblage-theoretic approaches do share significant conceptual common ground, notably their focus on particularity, localism and difference, and an insistence on the empirical "complexity" of socio-spatial arrangements. Planetary urbanism for its part concentrates on an attempt to reformulate the relationship between "concentrated" and "extended" forms of human settlement, land use, and spatial development by assimilating both of them into a theoretical urban landscape that is nothing less than global.

We will question these three approaches in a variety of ways.. We will argue that each of them contains major blind spots and analytical distortions and that each has failed to offer a meaningful concept of urbanization with generalizable insights about the logic and dynamics of cities. These weaknesses are not only regrettable in their own right, but are notably disabling in a field where the need to frame viable policy advocacies in search of social justice has become more and more insistent. In addition, we will argue that much of the current literature associated with these three approaches shares a predilection for certain kinds of convoluted philosophical and epistemological abstractions that actually present barriers to any understanding of the urban as a concrete social phenomenon. We begin our discussion by briefly re-stating ideas developed in an earlier paper (Scott and Storper (2015)) where we seek to establish a foundational concept of the urban. On that basis, we claim that there are fundamental common genetic factors underlying urban patterns, and a robust set of conceptual categories within which urbanization processes and urban experiences can be analyzed, wherever they may occur in the world. We then proceed to discuss in some detail what we take to be the most egregious weaknesses of the three main targets of our critique. As we work through this agenda we also offer a few replies - though less than a complete response -- to a number of critical assessments of our earlier paper.

\section{The Nature of Cities Revisited}

Towards an analytical understanding of the city 
In Scott and Storper (2015) we dwelt in part on the high levels of diversity and disagreement in urban theory over the last century or so, and we asked if a coherent, stable theory of the city could be constructed. Such a theory, if it were possible, would need (a) to account for the genesis of cities in general, (b) to capture the essence of cities as concrete social phenomena, and (c) to make it possible to shed light on the observable empirical diversity of cities over time and space.

Our approach to this theory-construction challenge was to build on the observation that cities are everywhere characterized by agglomeration involving the gravitational pull of people, economic activities, and other relata into interlocking, highdensity, nodal blocks of land use. The primary, but by no means the only mechanism driving this fundamental tendency, we argued, is the emergence of organic divisions of labor in which social and economic life (i.e. the production of goods and services, but also including cultural, religious and governmental pursuits) is organized and reorganized within networks of specialized but complementary units of human activity. This form of organization means, in turn, that mutual geographical proximity or agglomeration of these units is crucial, for otherwise the time and distance costs of interaction would impede their operational effectiveness. In our earlier paper, we argued at length that all cities throughout history are based on this fundamental process of agglomeration The costs of covering distance were no doubt much higher at earlier periods of history, but as the copious literature on agglomeration dynamics reveals, proximity through co-location is imperative for certain types of activities even today (Cooke and Morgan 1998; Fujita and Thisse 2002; Krugman 1991; Scott 2012; Storper 2013). A further major point must now be made to the effect that since the interdependent specialized activities that constitute the division of labor (and the residential housing associated with them) cannot all occupy a single point, they must necessarily sort themselves into a spatially extensive lattice or patchwork organized around their common center of gravity and characterized by intricate internal patterns of geographic differentiation. We call any system of this sort an urban land nexus (cf. Scott 1980).

These trans-historical and trans-geographical urban processes take on specific concrete attributes that reflect the wider - and ever changing - social, economic and political conditions within which urbanization is always embedded. We can identify five 
basic variables or forces that shape the principal variations of the urban land nexus at different times and places. These can be enumerated as (a) the overall level and mode of economic development, (b) prevailing resource allocation rules, (c) forms of social stratification, (d) cultural norms and traditions, and (e) relations of political authority and power. We do not have the space here to work out even a schematic description of the empirical diversity that these (and other) contextual variables are capable of generating, but they lead to a great deal of detailed variation in the urban land nexus from one instance to the next. For example, Imperial Rome, Xi' an in China, ancient Babylon, Timbuktu in the Empire of Mali, Tenochtitlan in $15^{\text {th }}$ century Aztlán (contemporary Mexico), Manchester in the industrial era in Britain, and Los Angeles, Mexico City, and Hong Kong in the $21^{\text {st }}$ century are all quite different from one another at one level of analysis, even as they all share in a common set of fundamental genetic forces. In view of the play of these differentiating variables, and notwithstanding our theoretical generalizations regarding the urban land nexus, we disagree with Dick and Rimmer (1998) who state that cities in various far-flung parts of the world are now converging towards a standard template. For the same reason, we also reject the claims of Roy (2015) when she describes our earlier paper as an attempt to construct a universal history whose objective is to obliterate "historical difference."

Not only does our analysis provide us with the tools for distinguishing between the general and the particular in urban outcomes, but also to separate out that which is distinctively and inherently urban from the rest of social reality. In particular, we must distinguish between phenomena that occur in cities but are not generated by urbanization processes as such, from phenomena that are legitimately elements of cities in the sense that they play an active role in defining the shape and logic of urban outcomes. Thus, a hospital located in an urban area will usually play an important role as an element of the urban land nexus, both as a specific kind of service provider and as a catchment point for those who use its services, but its internal administrative arrangements are not likely to be of much relevance to any understanding of the city. Similarly, the interest rate, ideologies of imperialism, or the price of sugar are not intrinsically urban; or rather, they can be said to have urban significance only insofar as they can be shown to play some role in the dynamics of the urban land nexus. A further illustration of these remarks is offered by the 
phenomenon of poverty, which has important urban dimensions, but also has many substantive and relational manifestations that are not generated by the urban as such. To state this in another way, measurements of inequality or poverty in cities are not equivalent to the claim that inequality or poverty are basically engendered by cities (Sampson, 2012). In capitalist or market economies especially, poverty is not fundamentally caused by urban processes, but by the complex forces that shape income distribution in an economy marked by private property, competitive markets and wage labor. Equally, although researchers often use urban entities as units of observation in various kinds of statistical exercises (just as we use counties, states, or countries for the same purpose), this alone does not endow these exercises with intrinsically urban meaning. The claim that any phenomenon occurring in a city is urban by nature is without further specification - liable to the error of ecological fallacy. Political outcomes in the city, too, need to be carefully scrutinized in order to distinguish the specifically urban from what is merely contingently so. In particular, the urban land nexus is by its very nature subject to peculiar and endemic forms of politicization. The tensions created by competition for land uses, the urge to secure access to positive externalities and to avoid the effects of negative externalities, the rent-seeking behavior of property owners, and the need to protect or enhance certain kinds of urban commons (such as agglomeration economies), among other frictions, all create constantly shifting circles of urban social collisions. Urban governance arrangements, too, or what Molotch (1976) called the urban "growth machine" are in significant ways caught up in these frictions through their functions as suppliers of public goods and services and their role as mediators of urban conflicts.

From these comments it follows (and even though we have affirmed that we live in an urban era in the sense that cities formally represent the principal geographic containers within which contemporary human society unfolds) that not all aspects of life, perhaps not even most aspects, can be understood as being necessarily (that is, "ontologically") urban phenomena in the very specific meaning as identified here. For these reasons, too, we are reluctant to accept Lefebvre's (1970) proposition that we are evolving in the direction of a full-blown "urban society" with its implied sub-text to the effect that society and the city are becoming one and the same thing. Similarly, the 
remark by Taylor (2013) that cities constitute the essential motors of all human society, politics, and economy throughout history and that hence all social science must become “city-centric," is clearly exaggerated. With a conscientiously delimited and focused concept of the city it is possible to identify how the urban generates specific kinds of social phenomena and sets them apart from non-urban phenomena. This is what provides a distinctive place for urban analysis in the academic division of labor and what, together with an appropriate analytical machinery, endows it with a central mission.

\section{$\underline{\text { Some practical and theoretical implications }}$}

The urban land nexus emerges in the first instance out of dynamics of agglomeration and accompanying processes of land-use sorting, thus generating a complex lattice of locational activities over a shared gravitational field. In capitalist systems, significant parts of the urban land nexus are subject to the rule of private property and are hence commodified. In other types of social systems, land use decisions are apt to be directed by different kinds of mechanisms involving, say, limited or non-existent individual property rights or communal regimes of ownership (such as ethnic or clan rule).

Whatever the system, individual units of land ownership always have more than a purely private, atomized dimension. More specifically, agglomeration, proximity, and density result in many different kinds of externalities (positive and negative) that circulate through the urban land nexus so that land use at one location invariably has impacts on other locations. Positive outcomes from agglomeration include processes of sharing (e.g. the joint usage of large-scale infrastructural artifacts), matching (e.g. the local availability of many alternative choices to purchasers and sellers of goods, services or labor), and learning (e.g. the rapid diffusion of cultural or technological information) which in part accounts for the dynamism we typically associate with cities throughout history and especially in capitalism (cf. Duranton and Puga 2004). Negative outcomes may include the congestion, land use incompatibilities, incentives to crime, segregation and inequality, social conflicts, and other undesirable consequences that arise out of the dense coexistence of highly differentiated social and economic activities in a relatively restricted spatial orbit. The importance and pervasiveness of these effects means, as 
already suggested, that some form of collective, non-individual control is necessary if the city is both to avoid internal blockage and if the individuals, households, and firms that it contains are to seize jointly on strategic developmental opportunities. This explains in large degree why the individual decision-making and behavioral mechanisms of the urban land nexus are virtually everywhere regulated by collective governance arrangements designed to safeguard cities against implosion and stagnation (Roweis and Scott, 1977). Within the city, interrelated units of economic production typically form distinctive clusters interpenetrated by swaths of residential activity. Areas outside the city are sources of the food, resources, and materials that are not produced internally; and they offer, in addition, markets for the city's tradable, specialized products. These areas are represented both by the immediate hinterland of the city and other cities and regions at more distant locations. Even in ancient times, long-distance trade was characteristic of many cities, as exemplified most dramatically by the case of Classical Rome. In the 21st century, cities interact with one another in a globally-integrated system of trade and information exchange as expressed in an emerging global mosaic of cities and cityregions.

In the light of these remarks, we can now state that the city represents a very specific scale of economic and social interaction generated by agglomeration processes and focused on the imperative of proximity, and almost always endowed with governance arrangements that attempt to deal with the problematical effects of density and propinquity. At the same time, the city is always embedded in a far-flung spatial economy that sustains it without compromising its integrity as a distinctive social phenomenon (Fujita, Krugman, and Venables 1999). Accordingly, as we shall argue in more detail later, it cannot simply be dissolved away by fiat into a sort of overarching global plasma as theorists of "planetary urbanization" proclaim (e.g. Angelo and Wachsmuth 2015; Brenner and Schmid 2015). Our argument thus goes strongly against the grain of the main theses of planetary urbanists or those who, like Amin and Thrift (2002), claim that "the city is everywhere and nowhere." A fortiori we stand in opposition to those urbanists who state that the idea of the city is purely ideological; and in view of our characterization of the urban land nexus as an overarching phenomenon that 
integrates urban space into a coherent social unit, we reject the Roy’s (2015)

characterization of the city as a thing of "shards and fragments."

This is also an appropriate moment to allude to some of the criticism that has been made of our earlier analysis on the grounds that it is "economistic" (Mould, 2015; Roy 2015). Given the primary role that we ascribe to economic forces in the genesis of the urban land nexus, this line of critique is entirely predictable but essentially misinformed. We assuredly do propose that the origins of the urban land nexus reside in the economic tensions engendered by the division of labor and agglomeration, (and we offer strong justifications for this position), but our claim is very far indeed from any argument to the effect that cities are exclusively or monocausally structured by economic variables. Indeed, we have explicitly suggested that diverse other social, cultural, and political forces are also at work in shaping the urban land nexus. Accordingly, our response to the charge of economism is twofold. On the one hand, we invite our critics to identify exactly what it is that they mean by "economism" (a term that is almost always vacuous in actual usage ${ }^{2}$ ). Our own suggestion here is that the most demanding sense in which the term can be used is to reserve it strictly for situations where that which is not economic is erroneously proclaimed to be economic (e.g. claims to the effect that the level of economic development determines the form of sociability in urban neighborhoods or that the city is nothing but an economic phenomenon). On the other hand, we challenge our critics' attempts to characterize our work as economistic by asking them to go beyond purely gestural allegations and to demonstrate in disciplined critical detail how our formulations about the analytical origins of cities might actually be wrong and how they can be corrected. In fact, a close reading of our text should make it abundantly clear that our theory of the urban land nexus remains open to an enormous diversity of noneconomic elaborations and hybridizations, and, indeed, to any number of complex reflexive relations between the economic and the social, political, and cultural

\footnotetext{
${ }^{2}$ Much the same can be said for the term "determinism" that Mould (2015) invokes in criticism of our earlier paper. Any self-respecting determinist is likely to insist at a minimum that a deterministic approach involves the suppression of free will in favor of purely material or structural-functional causalities. Mould mobilizes no reasoning or evidence as to how or why our theory of the urban land nexus involves any conception of this sort.
} 
dimensions of urban life. Moreover, although this point surely should not need to be made explicit, the urban land nexus obviously is a fundamental key to understanding the city as a locational matrix of built forms and associated symbolic assets, which, according to the views of Walker (2016), are culpably absent from our own analysis.

This brief exposition of our theoretical views now serves as a point of reference against which we will review and criticize a number of currently fashionable theories of urbanization that we take to offer seriously flawed accounts of both the scientific and political challenges posed by cities today.

\section{Postcolonial Urbanism: Cosmopolitan but Provincial}

Much contemporary postcolonial research originated in cultural and historical studies where it has functioned as a critique of numerous blind spots in Northern traditions of theoretical analysis. Above all, postcolonial thinking, as represented, for example, by Said (1978) and Spivak (2008) demonstrates how diverse intellectual legacies of colonialism (ethnocentric biases and prejudices in particular) enter unconsciously into scholarly writings about the Global South. Postcolonial scholars (such as Comaroff and Comaroff (2012)) are also, and correctly, intent on showing that the claims of universality that Euro-American theory has often arrogated to itself are sometimes demonstrably false. These same lines of thinking and critique have recently become strongly influential in urban studies. Robinson $(2006,2011)$ and Roy $(2009$, 2011) among many others, (for example, Edensor and Jayne 2012; Myers 2014; Ong and Roy 2011; Patel 2014; Sheppard, Leitner, and Maringanti 2013) have been notably vocal in this regard, and have been especially outspoken in decrying the application of urban theories constructed in Europe and North America to cities in the Global South.

These and other analysts have sought to correct what they see as imbalances and misrepresentations in Northern urban theories by means of two overlapping strategies. One is to call for more cosmopolitan forms of urban theory (what Ong and Roy (2011) refer to as "worlding") that take seriously the experiences of the cities of the Global South. The other is to insist on the irreducible core of idiosyncrasy that marks every city and to focus on the resulting play of empirical "difference" and "complexity." A further 
important point of departure for postcolonial urban scholars resides in the notion of the “ordinary city" developed by Amin and Graham (1997) to the effect that cities are all equally distinctive and unique and that none can be claimed to function as a privileged archetype or exemplar relative to the others. Robinson (2006) in particular, has appealed to this notion as by way of asserting the equivalent standing of all urban centers across the North-South divide, as well as by way of proclaiming that any meaningful problematic of the urban must focus intently on the essential character of cities as sites of difference. In a more radical vein, Roy (2009, p.820) has advocated sweeping much of extant urban theory away with the peremptory injunction that "the center of theorymaking must move to the Global South”. However, as Peck (2015) points out, there is an apparently unresolved tension in postcolonial studies between constant calls for a worlding of urban analysis on the one side and the equally constant affirmation of a North/South binary on the other, and even, in some cases, as we shall see, a tendency to favor a wholesale "provincialization" of urban theory (Ren and Luger 2015).

Postcolonial commentators are especially dissatisfied - not always incorrectly but frequently without appropriate nuance -- with what they allege to be the pervasive modernist and developmentalist biases of urban theory as elaborated in the Global North. One of the most baleful cases of this kind of bias, in the view of these commentators, is represented by the Chicago School of Urban Sociology. A particular point of contention is the Chicago School's notion of the folk-urban continuum comprising primitive, nonurban social formations on the one side, and advanced, urbanized social formations on the other, and the extension of this notion in the work of Wirth (1938). Postcolonial urban theorists criticize modernism-developmentalism as a discourse that consigns the cities (and societies) of the Global South to the status of underdevelopment and backwardness, an outlook that is manifest, according to Roy (2011, p. 224) in "apocalyptic and dystopian narratives of the slum." She herself sees the poverty, informality, marginalization, and extensive slums of Southern cities as a mode of urbanization (Roy, 2005; emphasis in the original). Quite what this phrase might mean is difficult to determine, but it presumably functions as a gesture intended to eliminate the allegedly pejorative implications of Northern theory. Modernism-developmentalism is further criticized by postcolonial scholars for its promotion of a teleological concept of cities in 
the Global South in which growth and change are alleged to be subject to evolutionary stages involving shifts from less to more modern and developed. The more specific claim here is that it is unreasonable to expect any linear movement from less formal to more formal arrangements in regard to settlement-building and property rights in the cities of the Global South (Roy 2005)

\section{The critique of postcolonial urban studies}

Obviously, cities of the Global South have been severely overlooked in past research efforts ${ }^{3}$; obviously we must be careful to pay attention to the specificities of these cities; and obviously, we need to acknowledge that urban theory must now range over the entire world for its sources of data and evidence while remaining fully open to new conceptual insights generated out of the experiences of the cities of the Global South. Equally obviously, we must beware of the dangers of Eurocentrism, by which we mean theoretical overreach based on limited evidence derived from Northern cities, but that is inappropriate or irrelevant with respect to Southern cities. Where postcolonial urban theory errs, we argue, is in its own peculiar forms of critical overreach and its overall commitment to what we have called a "new particularism" (Scott and Storper 2015). In what now follows, we address what we take to be three major failures of postcolonial urban theory, namely, its exaggerated complaints regarding Euro-American epistemological bias in contemporary urban analysis, its highly selective critique of modernism-developmentalism, and its strong methodological commitment to theoretically-unstructured comparativism. Note that all of these themes are essentially branches of a single meta-claim, that of a set of incommensurabilities: in point of view, in development, and in representativeness.

\section{Eurocentrism and the provincialization of knowledge}

\footnotetext{
${ }^{3}$ And now that opportunities for research on the cities of the Global South are expanding apace throughout the North and the South this relative neglect on the part of urban scholars will presumably fade rapidly away.
} 
To begin, then, postcolonial urban studies are broadly motivated by the claim that theory produced in the Global North is inescapably unable to account for empirical situations in the Global South (see Peck (2015) for an analogous characterization of postcolonial theory). Roy (2009) adds the further damning claim that Euro-American urban theory "... keep(s) alive the neo-orientalist tendencies that interpret Third World cities as the heart of darkness, the Other" (though we can think of no scholarly paper on cities published in at least the last half-century that would bear this assertion out). In harmony with these judgments, many urban theorists with a postcolonial bent (notably Sheppard 2014; Sheppard, Leitner, and Maringanti 2013) state that theories must necessarily be local and confined in their empirical reach to specific segments of geographic reality. As Leitner and Sheppard write (2015)

"... no single theory suffices to account for the variegated nature of urbanization and cities across the world, without asserting the necessity of different distinct theories for different contexts."

And:

"Our position, then, is that there can be no single urban theory of ubiquitous remit."

Even though the authors fail to define what they mean by "different contexts" and how we might identify them, they then go on to call for self-conscious "provincialization" of urban theory as a virtue in itself and as a way of delegitimizing what they see as the pervasive pretensions to universalism of European and American urban theory.

A first direct and simple answer to this call to provincialize theory is to ask for a clear and direct demonstration of the fundamental incommensurability of urban phenomena in different parts of the world, above and beyond assertions about empirical diversity. A second is to propose a counter-argument, as we have done (and which we offer for disconfirmation), to the effect that there are indeed theoretically generalizable features of urbanization as a whole. Of course, we know from the work of Livingstone 
(2014) and others that theoretical work very often does unconsciously reproduce geographical and ideological biases reflecting the circumstances in which it arises, and urban theory is no exception to this observation. Moreover, various streams of philosophy and historiography, most especially since the middle of the 20th century, clearly recognize the social constructivist character of all intellectual activity (Haraway 1988; Mannheim 1952; Kuhn, 1962). This work points not only to the essential social and historical foundations of all forms of discourse, but also to the absence of any Archimedean point from which knowledge claims can be fully and finally adjudicated. These comments signify that knowledge is always provisional and motivated by human interests (Habermas 1971), and in some cases (e.g. imperialist accounts of dominated peoples) can be grotesquely distorted representations. So far so good. It by no means follows, however, that ideas can never attain to universal value, or, more simply that an idea developed at place $a$ must invariably fail when transferred to place $b$. This is a matter for step-by-step judgment, not for a blanket diktat. By contrast, commitment to the notion that theories must be provincialized as prescribed by Leitner and Sheppard (2015) calls for a clear identification of what constitutes a meaningful "province," and in the absence of any operational guidelines in this matter (as in the work under evaluation here) amounts to little more than an arbitrary and self-defeating preference for intellectual parochialism at the expense of more searching theoretical generalization. At the same time, and as a corrective to the one-dimensional critique of Northern theory that is offered by postcolonial urban scholars, many of these same issues of bias and ethnocentricity are ones that theorists have struggled with since the Enlightenment, above all in regard to the question as to what constitutes the common or universal features of humanity and what in different contexts represents essential differences in human behaviors and aspirations (Pagden 2013). The tensions in this duality were especially prominent in European debates over the 18th and 19th centuries (and even as far back as the $16^{\text {th }}$ century if we consider Montaigne) about the nature of distant "others." We can see in more detail why the critique of "Northern" theory by postcolonial urban scholars is unduly one-sided by examining how these scholars deal with modernism and developmentalism. 


\section{Modernism-developmentalism}

There can be little doubt that some versions of modernist-developmentalist theory impose misguided concepts not only on the cities of the Global South but also on those of the Global North. The implausible mechanical model of stages of growth is one such theory. The same can be said for the organic-ecological model of neighborhood succession as developed by the Chicago School, which is especially suspect given its Darwinian undertones and its association with the concept of the folk-urban continuum (Robinson 2006).

Whatever the failures of these particular theories may be, scholars in both the Global South and the Global North are in practice faced with the evident empirical fact of the marked differences in levels of economic development and income exhibited by cities in different parts of the world and the effects of these differences on urban outcomes (cf. Smith 2013). Acknowledgment of the powerful role of economic forces in shaping the urban milieu is not to advocate any sort of teleology of urban history, with all cities everywhere eventually converging to a state of achieved "modernity." To the contrary, we recognize that the empirical trajectories of development followed by individual cities vary markedly, both within the Global South and North as well as within single countries. Over time, some cities grow at an accelerated pace; some grow rapidly and then decline; some remain in a proto-capitalist state of development; some are prosperous while others are impoverished; some specialize in manufacturing while others are more given to service provision; some have dependent branch-plant economies while others become centers of innovative high-income entrepreneurialism; and so on through any number of possible variations. Throughout all of this diversity, however, there remains the burning issue of how specific forms and levels of economic development shape specific variants of agglomeration and high-density land use -- in other words, the urban land nexus -- and how this in turn feeds back upon those same forms and levels.

Postcolonial scholars' fixation on the supposed exceptionalism of the Global South is particularly evident in their treatment of such favored themes as poverty, slums, informal labor markets, vulnerable property rights, inadequate infrastructure, and lack of sanitation (Roy 2005). These themes are frequently dealt with as though they had no family 
resemblance to similar issues in the Global North. Yet we only need think of Charles Dickens' London, Emile Zola's Paris, and Sinclair Lewis' Chicago, or more recent cases of deprivation and spatial exclusion in Europe and America revealed in the studies of Standing (2011), Wilson (1987), Sampson (2012) and Chetty et al., (2014) to recognize that there is much in common between the cities of the Global North and the Global South in regard to poverty, and that examination of the former has much to offer to scholars of the latter, and vice versa. These remarks lead on to consideration of postcolonial scholars' approach to developmental issues generally, and in particular, as Chibber (2013) points out, their claims about developmental theories in the Global North being simple and linear as compared with the experience of the Global South where development is said to be complex and non-linear. Of course, as we have already pointed out, these claims about Northern development theories are a misrepresentation. Many different formulations of the diverse Northern routes to development have long constituted one of the principal axes of debate within Northern historical research (Allen 2009; Aston and Philpin 1987). Even so, post-colonial scholars continue to assert these claims as background to their view that urban development of the Global South is so unique as to defy any theoretical description that might establish commonalities with cities elsewhere. In other instances, post-colonial scholars (such as Robinson (2011)) effectively shift questions about the interrelations between economic development and urbanization into the distant background as nothing but Northern theoretical fantasies irrevocably marred by Eurocentric parochialism, reductionism, and teleological thinking. In fact, in both the North and the South, despite many empirical differences of history and geography, the shifting forces of capitalism and markets and their expression in production, trade, and employment, pose a consistent set of conceptual problems. These include the ways in which capitalist and non-capitalist systems articulate with one another, as in the case of the co-agglomeration of producers in the informal and formal sectors in India as described by Mukim (2015; see also Rey, Duroux, and Bettelheim 1971) or the dynamics of informality in American cities offered by Mukhija and Loukaitou-Sideris, 2014. Certainly, there is much in the way of difference and idiosyncrasy to investigate in cities around the world, but theory is required for this sort of investigation to take on any wider meaning. We have posed a generalized theoretical 
framework of the urban land nexus intertwined with five crucial processes shaping the specifics of urbanization in different times and places (level of development; resource allocation rules; forms and levels of social stratification; cultural norms and traditions; authority and power). This framework precisely addresses the need to acknowledge diversity, but without falling into the sophism of particularism and thereby losing sight of the forces that affect all cities.

\section{Comparativism and its limits}

One of the ways in which postcolonial scholars seek to compensate for their deep skepticism about much current urban theory is by means of the "comparative gesture" stressing "thinking across differences" in ways that are "potentially open to the experiences of all cities" (Robinson 2014, p. 57). A comparative approach is especially congenial to postcolonial studies because it is assumed to reduce the dangers of aprioristic thinking about cities and the inappropriate imposition of alien concepts on given empirical situations. Myers (2014), for example, offers what is intended to be an

exemplary comparative account of multi-racial policy approaches to urban transportation policy in Capetown and Nairobi on the one hand and Hartford, CT., on the other. This account turns on the proposition that the experiences of these African cities in the matter of community development could have usefully informed the design of the Hartford-New Britain transportation corridor, and it is no doubt interesting and pertinent within its own limited terms of reference. Yet like so much other work in this comparative genre it signally fails "to transform existing conceptualizations" as optimistically promised by proponents of the genre (Robinson and Roy, 2015, p.3). Our own argument is that the well-travelled but narrow road represented by comparative and classificatory methods certainly adds a number of legitimate procedures to the social scientist's toolbox. However, if comparisons are to be effective, they can never proceed on the basis of theoretically uninformed choices about cases for comparison or the specific variables that are isolated for examination. Prior conceptual labor about these matters is essential if comparative methodologies are to produce - other than by accident or good luck -significant results. This means specifically that we need to have a degree of conceptual 
clarity or intuition about the issues under examination in order for comparison to proceed in a way that reveals consequential insights when different empirical situations are brought into conjunction with one another.

To be sure, the comparative gesture can be useful and interesting, but our point is that a more theoretically self-conscious pooling of data, experiences, and investigative results is essential if urban investigations are to progress beyond localism, difference, and the celebration of empirical complexity for its own sake. For this reason, there is much to be said in favor of identifying theoretically meaningful categories of cities that contain multiple cases of similar but not identical cities. This point is recognized by Robinson (2011), though her argument is strongly in favor of inductive analysis of the data. Other postcolonial urbanists appear to be rather more ambivalent about this issue. For example, Bunnell and Maringanti (2010) and Roy (2009), raise arguments against categories like world cities, international financial centers, and city-regions, not so much because they may be misidentified but because they are said, somehow or other, to relegate excluded cities to secondary status while supposedly diverting our attention away from the full diversity of urban forms and experiences that the world has to offer. Here again we come face to face with the new particularism and the relegation of all cities to the status of "ordinariness." This insistence on difference and idiosyncrasy within ordinary cities is especially evident in the case of another favorite target of postcolonial critique, i.e. the notion of the representative or exemplary city, and, notably, the writings of the so-called LA School about the "paradigmatic" status of Los Angeles towards the end of the $20^{\text {th }}$ century. We would be the first to acknowledge the incautiousness of many of the LA School's theses, and yet it is important to record that Los Angeles, in its pioneering status as a globalizing post-fordist center of flexible specialization, disorganized labor, growing social inequality, and polycentricity did indeed turn out to be an early and powerful expression of several incipient world-wide trends (Soja and Scott, 1986). Accordingly, the LA School called attention at an early stage to a developmental pathway that many other cities all over the world have subsequently followed, and from this perspective it was most certainly exemplary.

\section{McFarlane's Railway Ticket}


Over the last few decades, "assemblage theory" has emerged as a major genre of work in urban studies, as in the social sciences in general (see, for example, DeLanda 2002; Latour 2005). This theory, which has many affinities with postcolonial urbanism, has filtered into urban studies from the work of continental post-structuralist philosophers (in particular, Deleuze and Guattari 1972). Assemblage theory is of considerable complexity in its philosophical representations, the understanding of which is not made any easier by the langue de bois favored by its chief protagonists and the sharply conflicting interpretations of their work by secondary commentators. For our purposes, however, focused as they mostly are on abridged "applications" of this theory to urban analysis, a few essentials will suffice to motivate our critique.

Assemblage theory is first and foremost an ontological view of the world conceived as a mass of rhizomatic networks or finely-grained relationships constituting the fundamental character of reality. These networks bind together unique human and non-human objects within fluid, hybrid mosaics forming more or less temporarily stabilized systems of interconnections representing the current state of the observable world. Assemblages become stabilized by "territorialization" (as opposed to destabilizing deterritorialization) when they are anchored to particular tracts of geographical space. Importantly, any state of reality in this theory is taken to be "flat" in the sense that any perceived hierarchical or scalar ordering (from a top to a bottom) decomposes back again into the kaleidoscopic, rhizomatic, and horizontal relations that are said to constitute it (DeLanda 2002; see also Marston, Jones, and Woodward 2005). This point is largely shared between assemblage theory and postcolonial theory, via the latter's emphasis on difference and its focus on the incommensurable uniqueness of cities.

There are several variants of assemblage theory, but one of the most influential is actor-network theory, a body of ideas associated above all with the work of Latour (2005). This is, again, a way of exploring the multiple relationships that tie human and non-human objects together, but with the additional claim that all of these objects are constituted as actants, i.e. capable of agency in the sense that they exert effects on other actants. In a number of methodological and theoretical publications, Farías (e.g. 2010, 
2011) has outlined the main implications of assemblage and actor-network theory for urban studies. He writes that the city is

“... an object which is relentlessly being assembled at concrete sites of urban practice, or, to put it differently, as a multiplicity of processes of becoming, affixing sociotechnical networks, hybrid collectives and alternative topologies" (Farías 2010, p. 2).

Some of the multiple ways in which the urban might be assembled are then enumerated (p. 14)

“. . as a transport system, as a playground for skateboarders and freerunners (parkour), as a landscape of power, as a public stage for political action and demonstration, as a no-go area, as a festival, as a surveillance area, as a socialization space, as a private memory, as a creative milieu, as a jurisdiction, etc."

This conception then leads to a descriptive, anecdotal, and notably indiscriminate approach to urban investigation. Farías (2011, p.367) with apparent faith in the powers of inductive empiricism goes so far as to say that "we don't know what we are looking for until we find it." Little wonder, then, that Brenner et al. (2011) characterize this line of research as "naïve objectivism" and point to its failure to distinguish between the significant and the insignificant in urban analysis. Certainly, the assemblage approach is potentially of positive value in certain kinds of ethnographic and narrative accounts of the city such as those offered by de Boek and Plissart (2004), Mbembe and Nuttall (2004) or Simone (2014); and as Geertz (1973) has shown, thick description of social practices and material forms in cities or elsewhere can often provide sensitive depictions of the ways in which social lives are woven together. One example might be the complex manner in which we build high-rise downtown environments in major cities and the connections of this process to the construction industry, architectural practices and building norms, competing demands for space, visual conceptions of the built environment, and office 
employment in the city. Our critique of assemblage theory therefore does not deny the possibility of certain important feedbacks between non-human objects and human society and it is emphatically not intended to repudiate the reflexive relations between technology, urban space, and social life (cf. Graham and Marvin 2001). However, we certainly do have strong reservations about the capability of inanimate objects to "act" as if whatever causal or generative powers they may possess were ontologically equivalent to sentient, purposive human behavior.

Assemblage theory radically privileges the activity of assemblage itself, seeing no wider forces that might determine what assemblages are possible or not possible; rather, it advocates a methodology of building the elements of social organization a posteriori from the ground up (Bender 2010) and focusing on specific sites of daily life (Simone, 2011). The result is a largely indeterminate concept of the city as a complex, variegated, multifarious, open-ended, fluid, unique, hybrid, unruly, nonlinear, etc. etc., aggregate of disparate phenomena tied together in a haphazard mix of causal and contingent relationships. This concept, like Robinson's (2011, p.13) (postcolonial) view of the city as "a site of assemblage, multiplicity, and connectivity" is at one level of observation certainly correct, but at another level interposes mere empirical convolution as a substitute for a deeper and more systematic level of (theoretical) comprehension. This naïve objectivism frequently also results in markedly indiscriminate bodies of information being packaged into empirical assemblages, perhaps especially where, in the words Acuto (2011: 553) those "missing masses of non-human actors often degraded to the role of mundane artefacts" are brought into concatenation with human life. In other words, there are no theoretical guideposts in assemblage theory for telling us how tease out significant relationships or to distinguish between the trivial and the important.

We may further pin down these remarks by reference to the work of McFarlane (2011; 2011), another prominent spokesperson for assemblage theory. In his lively defense of this theory, McFarlane (2011, p. 216) draws on his research on poverty and informal housing in Bombay. He insists that any attempt to understand "the everyday lives and hardships faced by the poor" requires us to pay attention to an eclectic collection of "urban materialities," which include in this instance such disparate objects as sackcloth, corrugated iron, brick, breezeblock, hydroform, and infrastructures of 
drainage, sanitation, water, and electricity. These elements are then organized into a description of poverty in Bombay, but critically the account -- which has the analytically "flat" quality prescribed by assemblage theory - is essentially devoid of useful explanatory ideas. The same can be said for the analogous work of Dovey (2012), who, like Simone (2011) puts forth an extended display of deleuzoguattarian ${ }^{4}$ jargon in an attempt to illuminate descriptions of urban informality that nevertheless remain uninformative about the basic logic of social and economic marginalization.

The fetishization of inanimate objects as instruments of agency is dramatically highlighted in McFarlane's (2011, p. 217) discussion of the work of political activists in combatting poverty in Mumbai. He points to the way in which these activists discovered that they could make free telephone calls by inserting a railway ticket into a receiver, and by this means greatly extend their outreach. McFarlane then states that this is all part of the "experience and possibilities of urban life." Our point, by the way, is not to dismiss this kind of narrative as meaningless in principle. A good story is a good story, after all. Our point is rather that in the case of McFarlane's railway ticket a trivial contingency is in all seriousness offered as a link within a chain of agency that is supposed to function as a way of understanding urban poverty and as an informed account of the struggles that people engage in to escape from it. This picture sharply contrasts to the more analytically controlled realism about obstacles in the way of the poor that is painted by such diverse authors as Aw (2013), Boo (2012), Caldeira (2001) and Cole (2014). As Brenner et al. (2011, p. 233) write of actor-network theory:

"This mode of analysis presupposes that the 'facts' - in this case, those of interconnection among human and nonhuman actants - speak for themselves rather than requiring mediation or at least animation through theoretical assumptions and interpretive schemata."

Thus, in the flattened world of assemblage theory there is a perilous tendency to fail to distinguish between the inanimate character of material objects and the intentionality of humans, and to compound this oversight by undertheorized presentations of social interconnectivity (cf. Tonkiss 2011). This flattening of the world also evacuates any

${ }^{4}$ We use the term satirically. 
meaningful political content from assemblage theory since everything is equally important (or equally trivial and unimportant).

The principal problems of assemblage theory as discussed in this section of the paper -- the notion of reality as mere rhizomatic entanglements without underlying processes of structuration, the indiscriminate attribution of agency to things, and the absence of concepts of human action -- make this theory unable to detect urban dynamics, movement, change and causality in meaningful ways. Critical realism has long provided a way out of this kind of dead-end by insisting on the importance of necessary relationships, causal powers, and theoretical abstraction as fundamental to the identification of the central properties and conditions of existence of social phenomena (Sayer 2004). One searches in vain in assemblage theory and urban research based on it to know what larger difference assemblages make, which assemblages are important and which are insignificant and fleeting, which are empowering and which are disempowering, and what kinds of policy interventions are most likely to bring about desired forms of social change.

\section{Planetary Perplexities}

Some urban analysts today, most notably Brenner and Schmid (2015) suggest that in the 21 st century, a radical blurring of the category of the urban versus everything else has come about, and that what were formerly identified as urban areas can no longer be distinguished from the rest of geographic space, conceptually or empirically. These are the central doctrines of "planetary urbanism." As Brenner and Schmid (2014, p.750) write:

"It is clear that settlement-based understandings of the urban condition have now become obsolete. The urban cannot be plausibly understood as a bounded, enclosed site of social relations that is to be contrasted with non-urban zones or conditions. It is time, therefore, to explode our inherited assumptions regarding the morphologies, territorializations and sociospatial dynamics of the urban condition."

Given the geographically intensive and extensive development of global capitalism, the authors are doubtless correct to refer to an integrated planet-wide socio-economic system. They are also right to claim that the notion of a purely "rural" realm occupying the 
interstitial spaces between cities is archaic and misleading. The notion has never, in any case, been entirely satisfactory given the diversity of these territories (deserts, forests, mountain ranges, sites of peasant farming, expanses of industrial agriculture, spaces of resource extraction, tourist regions, etc.). But we are at a loss to understand how these facts can lead to a claim that the idea of the city, only "persists as an ideological framing" (Brenner and Schmid 2015, p. 152), a phrase that is echoed by Merrifield's (2013) characterization of the same idea as a "pseudo-concept." Above all, as we show below, Brenner and Schmid do not conclusively demonstrate that the city fades away as an identifiable geographic entity and scale of socio-economic interaction within planetary space, or that any distinction between the urban and the rest of geographic space (what they misleadingly insist on calling "the rural") must now be abandoned; and they are merely baffling when they write about the full extent of planetary space as being "urbanized," especially when this includes "rainforests, deserts, alpine regions, polar zones, and oceans and even the atmosphere" (Brenner and Schmid 2015, pp. 152-153). ${ }^{5}$

Brenner and Schmid hedge their bets rather clumsily by saying that there is something called "concentrated" urbanization, or what we usually call cities, and something called "extended" urbanization, which more or less corresponds to everything else. The puzzle is why they want to introduce the semantic confusion that ensues from applying the term "urban" with all its familiar city-centric connotations to everything else when numerous other descriptive terms are quite conceivable. ${ }^{6}$ We shall argue that not only is there no conceptual (or what they relentlessly call "epistemological") gain by this maneuver, but considerable theoretical loss. Here, Angelo and Wachsmuth (2015) enter the fray with their commentary on something that they allude to as "methodological cityism." They identify this forbidding sin with the error of ascribing to the circumscribed geographic structure of the city processes that they say are more

5 A detailed response to Brenner and Schmid has been offered by Walker (2015). His main lines of critique differ from ours, but are equally adamant about the integrity of the city as an object of theoretical enquiry.

6 For example, among the many possible alternative terminologies are: "global spaceeconomy," "planetary capitalism," or the "geographical anatomy of global society." These terminologies capture the spirit of what Brenner and Schmid seem to be saying, without obliterating the commonly received meaning of the term "urban." 
properly to be analyzed within the wider framework of Brenner and Schmid's "planetary urbanization." The plot thickens when Brenner and Schmid point out (correctly as it happens) that there are usually no simple or intuitively-identifiable boundaries between the city (concentrated space) and the rest of the world (extended space) so that the continuity between the two appears to be unbroken. This is a familiar problem that has always perplexed urban analysts, but Brenner and Schmid are wrong to think that the issue goes away by assimilating the whole of geographic space into an urban problematic. There is in fact a more satisfactory way of approaching this problem.

Consider, to begin with, certain kinds of phenomena that exist at the intra-urban level, such as neighborhoods, slums, industrial quarters, central business districts and suburbs. Each of these phenomena represents a distinctive and multifaceted type of sociospatial outcome within a wider urban space (the urban land nexus) and none is divided from the rest of the city by a clear line of demarcation. Yet each appears to us as an ontologically distinctive scale of urban space not only because of its empirical character but also because each poses uniquely problematical scientific and political questions deriving from its mode(s) of operation. Sampson (2012), for example, has shown that there are many and sundry "neighborhood effects" on people who live in poor communities, and Chetty et al. (2014), have shown how these effects also have an impact on intergenerational poverty rates. Similarly, the vast literature on local economic development reveals that intra-urban clusters of production units are marked by powerful spatial dynamics that are uniquely problematical as objects of inquiry. All of these phenomena are embedded in and marked by all manner of continuities with the urban land nexus, but in no case is it useful or meaningful simply to dismiss them as ideological constructions Two related points now need to be made.

First, the city is a composite social, political, cultural and economic phenomenon (anchored and integrated by the urban land nexus) that is very much greater than the sum of its parts, signifying, in turn, that it has a potent collective presence. In particular, the city is a site of joint dynamics with a joint identity (e.g. "the San Francisco Bay Area," "Rio de Janeiro") deriving from its character as an agglomerated land nexus. This state of affairs means that the wider political interests of the individual firms, households, and other behavioral units that make up the urban sphere, become entangled with a concrete 
set of political interests specific to the city (including those forms of conflict, coalition, exclusion and deprivation peculiar to the urban land nexus). These political interests are partly mobilized in collective action and are almost always associated with formal institutions (especially governmental institutions) that endow cities with powers of taxation, managerial regulation and the capacity to make substantial public investments). Among the more important concerns of these institutions is the performance of the city as a center of employment, earnings, and quality of life, again rooted in the urban land nexus (Molotch, 1976). For all of these reasons, the city at large -- especially given its foundations in agglomeration and its dense institutional and political overlay -- poses questions that are quite specific to the urban arena both as an object of scientific enquiry and as a scale of human political and economic life. This is why proponents of so-called methodological cityism are mistaken in their characterization of the city as nothing more than an ideological mirage

Second, just as neighborhoods, slums, industrial quarters, etc., are distinctive and idiosyncratic socio-spatial articulations (albeit within the urban land nexus), so the urban land nexus itself is a distinctive socio-spatial articulation (within wider global or planetary space). The city, in a nutshell, is in important ways an irreducible collectivity, and as we argued earlier, its peculiar character derives from its properties as a locus of agglomeration, gravitation, and density as well as from its specific daily and weekly rhythms of life. These rhythms are embodied most notably in its local labor markets and its regular patterns of commuting (Cheshire and Hay 1989; Kerr and Kominers 2015). To state this latter point in another way, cities concern us because distance is not dead, and substantial elements of our lives are anchored in these spatially-and temporallyconstrained urban systems. The day when we can move with no cost in time or effort from one place to another (i.e. a world of "magic carpets") is the day when can say that the city is dead. But the overwhelming situation in the contemporary world is one in which - despite the growth of long-distance linkages - proximity and density remain critically important as arrangements that facilitate the still expanding volumes of detailed, small-scale, intimate, and ever-changing interactions that lie at the heart of human relationships within the urban land nexus. 
There remains an unanswered question. Even given the above discussion, where and how do we draw the dividing line between the city and the rest of geographic space? We have argued, with specific reference to the city, that in spite of the continuity/indivisibility of geographic space (or of reality as a whole for that matter) there are differing scales and articulations of empirical phenomena, underlying processes, and political interests that make it imperative to distinguish specific units and levels of interaction within the totality of planetary space as a whole. Moreover, there is no rigid line that separates the urban land nexus definitively from the rest of geographic space, but rather a series of spatial gradations in which we move from the one to the other. This does not mean that the urban land nexus and its dynamics as identified above are illusions, just as neighborhoods, slums, industrial quarters, etc., do not dissolve away into an urban totality, and just as the fact that the seasons fade gradually and unevenly into one another does not mean that they do not exist as identifiable phenomena in their own right. The evident deduction from these remarks is that we almost always have considerable leeway in practice as to how we demarcate the spatial extent of the urban land nexus, but that the best bet is to define it in any given instance in a way that optimizes our ability to deal with whatever given question(s) we may have in hand (e.g. economic development, public transport, ethnic conflict, neighborhood blight, urban political strategy, and so on) while eliminating from consideration as much irrelevant territory as possible. In practice, we have little option but to follow the pragmatic rule of thumb that has always been adopted by geographers and to locate the line of division in some more or less workable way relative to available data.

One possible objection to these lines of reasoning is that cities have diverse functional connections to other places in many different parts of the world. Indeed Brenner and Schmid, (2014, 2015) among others (e.g. Amin and Thrift 2002), make the explicit claim that the identity of the city as a spatial unit is deeply compromised by the widening external relations that form its so-called "constitutive outside.". Our response here is simple. These relations are capable of inducing certain kinds of changes in cities, such as bursts of growth in central business districts or changes in given population categories, but their effects are virtually always assimilated into the urban land nexus as such without destroying its integrity as a complex social unit. For example, the New 
York financial district has strong external connections to far-flung customers and sources of capital, resulting in the growth of local firms with diverse impacts on land use patterns in Manhattan and on workers' residential behaviors,. Whatever the effects of the constitutive outside of the city may be, however, these in no way undermine the theoretical notion of the urban land nexus as the critical constitutive inside of the city. Indeed, the urban land nexus gains in terms of its internal complexity even as these effects intensify and multiply. Equally, and despite the fact that in the world system of the $21^{\text {st }}$ century spatial interconnections have attained unprecedented levels of volume and geographic extension, the need for proximity and local interaction has in many ways been bolstered within the urban land nexus (Hummels (2007); Duranton and Storper (2008)). Anderson and van Wincoop (2004), for example, have demonstrated that trade costs remain so important in today's world that they frequently reinforce a distinctively local scale of interaction. We should point out in any case that long-distance interconnections between cities have always been a feature of urban life, beginning in Jericho, 6,500 years ago, and as we have already stated, they are typically a crucial condition of continued urban viability. As such, they do not represent the negation of the identity of the city but one of the conditions that have made the existence of cities possible throughout history.

\section{Summing-up: a challenge to urban theory and research}

We have tried in all of the above to blast open a number of theoretical geographies of cities and urbanization processes, and we have criticized in particular certain recent trends that for one reason or another deform or mischaracterize or conceal the essential functions and identity of the urban. At the same time, we have offered as background to our critique a concept of the city as a tangible phenomenon, distinct from but contained within society as a whole, and with specific genetic roots and unique internal organizational dynamics. This concept allows us to distinguish what is authentically urban from the merely contingently urban and hence to bring a degree of disciplined focus to the investigation of urban matters. We should add that precision of 
ideas in this respect is especially important in policy-relevant research (see Scott and Storper 2015).

Against the backdrop of our own propositions about the nature of cities, we have examined three influential alternative views on urban matters, namely postcolonial theory, assemblage-theoretic approaches, and planetary urbanism, and found them wanting. Postcolonial commentators argue for an approach to urban studies that is simultaneously provincial, comparativist, and focused on difference, which in practice means particularity. While they invoke ambiguous notions of "worlding" they reject as a matter of principle the transfer of analytical results from cities of the Global North to cities of the Global South and by the same token any generalized theoretical concept of the urban, and presumably (at least for purists) any trans-provincial fertilization of ideas.

Assemblage-theoretic approaches have much in common with these features but in addition are intent on portraying social outcomes as relational kaleidoscopes in everchanging combinatorial arrangements that offer few or no insights as to the genetics of indurated spatial and institutional arrangements. Not only are assemblage and actornetwork approaches to the city notably weak in grasping fundamental social and economic processes, but they compound this weakness by suggesting that purely passive things lacking in intentionality and social discretion, like the door hinge mentioned by Acuto (2011), or the scallops studied by Callon (1984), or the railway ticket that enters into the account of poverty by McFarlane (2011) are endowed with powers of agency akin to those of human subjects.

It should be noted that while postcolonial and assemblage-theoretic commentators have strong views about the conduct of urban research, none of them offers any coherent concept of the urban as such. Planetary urbanists for their part make strong claims about the deliquescence of the city as commonly understood and the assimilation of the urban into a world-wide space-economy. They provide little in the way of conceptual valueadded by this maneuver while gratuitously deforming the usually accepted meaning of the term "urbanization" pointing, as it does, to agglomeration, density, and nodality and, by extension, to distinctive political, social, economic and identity-forming processes at the urban scale. Our own propositions regarding the material and relational structures of the urban land nexus suggest that the claims of planetary urbanists about the supposed 
waywardness of what they call methodological cityism and about the purely ideological status of the concept of the city are in the end seriously mistaken.

At least some of these aberrant tendencies in contemporary urban theory can be traced back to a remarkably uncritical faith among many contemporary analysts in the ability of abstracted philosophical ideas to orchestrate the shape and form of concrete investigations of cities. We are not opposed to incursions of philosophical ideas into the work of urban theorists; far from it. We are only too aware of how necessary philosophically-based criticality and clarity are to viable social analysis. Our concern here is focused primarily on what we take to be the unfortunate influence of poststructuralist philosophy in urban studies. We are referring here, first, to the semanticallyinflated jargon that mars so much of the literature today. More importantly, and second, we also point to the overblown interpretative schemas that post-structuralism licenses and their tendency to crowd out analytically-oriented forms of social (and especially economic) enquiry in favor of a conceptually barren search for difference, particularity and localism. The ontologies of flatness favored by post-structural theory are equally damaging to the vibrancy of urban studies especially in their denial of scalar dimensions to space in a manner that effectively dissolves the city away as a structured sociogeographic entity, and this encourages in turn a rampant eclecticism so that the city as such tends to shift persistently out of focus. Planetary urbanists are also at pains to secure this same dissolution, but this time on the basis of an enigmatic "epistemology" that in practice stands in for some rather unexceptional, and, in our opinion, imperfectly digested observational statements. To repeat the message of our opening line, the current period of history can most certainly be characterized as an urban era, in the sense that more and more of humanity lives in distinctively urban settlements. If we are to come to some sort of understanding of the new and daunting challenges posed by this state of affairs (including a clear understanding of what is and is not ascribable to urban processes in modern life), we need an urban theory that is fully up to the task. We have tried to clear away some of the obstacles that we argue stand in the way of the accomplishment of this goal, and to propose some essential groundwork for building more effective theories of the urban and the urbanization process. 
Finally, we strongly advocate abandonment of the classification of cities in terms of a Global North and a Global South with its curious echo of First and Third Worlds. Postcolonial theorists, of course, have their own reasons for hewing to this terminology, and we ourselves certainly have no intention of suggesting that colonialism, even today, has not left deep traces on many different parts of the world and in many domains of human enquiry. That said, and in view of the prevailing, many-sided patchwork of spatial outcomes exhibiting many different empirical varieties of economic and political development in today's world, this schematic binary is quite definitely inadequate as an organizational framework for huge swaths of contemporary social investigation, and nowhere more so than in the case of urban studies.

\section{$\underline{\text { References }}$}

Acuto, M. 2011. Putting ANTs into the mille-feuille. City 15: 552-562.

Allen, R C. 2009. The British Industrial Revolution in Historical Perspective Cambridge: Cambridge University Press.

Amin, A, and S Graham. 1997. The ordinary city. Transactions of the Institute of British Geographers 22: 411-429.

Amin, A, and N Thrift. 2002. Cities: Reimagining the Urban. Cambridge: Polity.

Anderson, J E, and E van Wincoop. 2004. Trade costs. Journal of Economic Literature 42: 691-751.

Angelo, H, and D Wachsmuth. 2015. Urbanizing urban political economy: a critique of methodological cityism. International Journal of Urban and Regional Research (39): 16-27.

Aston, T, and C H E Philpin. 1987. The Brenner Debate: Agrarian Class Structure and Economic Development in Pre-Industrial Europe. Cambridge: Cambridge University Press.

Aw, T. 2013. Five Star Billionaire New York: Random House.

Bender, T. 2010. "Postscript: reassembling the city: networks and urban imaginaries." In Urban Assemblages: How Actor-Network Theory Changes Urban Theory, eds. I Farías and T Bender. London: Routledge. 303-323.

Boek, F de, and M-F. Plissart. 2004. Kinshasa: Tales of the Invisible City. Antwerp: Ludion.

Boo, K. 2012. Behind the Beautiful Forevers: Life, Death and Hope in a Mumbai Undercity. New York: Random House.

Brenner, N, D J Madden, and D Wachsmuth. 2011. Assemblage urbanism and the challenges of critical urban theory. City 15: 225-240.

Brenner, N, and C Schmid. 2014. The urban age in question. International Journal of Urban and Regional Research 38: 731-755. 
- 2015. Towards a new epistemology of the urban. City 19: 151-182.

Bunnell, T, and A Maringanti. 2010. Practising urban and regional research beyond metrocentricity. International Journal of Urban and Regional Research 34: 415420.

Callon, M. 1984. Some elements of a sociology of translation: domestication of the scallops and the fishermen of St Brieuc Bay. Sociological Review Special Supplement S1: 196-233.

Cheshire, P, and D Hay. 1989. Urban Problems in Western Europe: An Economic Analysis London: Hyman.

Chetty, R, N Hendren, P Kline, and E Saez. 2014. Where is the land of opportunity? The geography of intergenerational mobility in the United States. Quarterly Journal of Economics 129: 1553-1623.

Chibber, V. 2013. Postcolonial Theory and the Spectre of Capitalism. London: Verso.

Cole, T. 2014. Every Day is for the Thief. New York: Random House.

Comaroff, J, and J L Comaroff. 2012. Theory from the South: How Euro-America is Evolving toward Africa. Boulder: Paradigm.

Cooke, $\mathrm{P}$, and K Morgan. 1998. The associational economy: firms, regions, and innovation. Oxford: Oxford University Press.

DeLanda, M. 2002. Intensive Science and Virtual Philosophy. London: Continuum.

Deleuze, G, and F Guattari. 1972. Capitalisme et Schizophrénie. Paris: Editions de Minuit.

Dick, H. W., and P. J. Rimmer. 1998. Beyond the Third World city: The new urban geography of South-East Asia. Urban Studies 35: 2303-2321.

Dovey, K. 2012. Informal urbanism and complex adaptive assemblage. International Development Planning Review 34: 349-367.

Duranton, G, and M Storper. 2008. Rising trade costs? Agglomeration and trade with endogenous transaction costs." Canadian Journal of Economics 41: 292-319.

Duranton, G., and D Puga. 2004. "Micro foundations of urban agglomeration economies." In Handbook of Regional and Urban Economics, Vol. 4, eds. J V Henderson and J F Thisse. Amsterdam: Elsevier. 2065-2118.

Edensor, T, and M Jayne. 2012. "Introduction: urban theory beyond the West." In Urban Theory Beyond the West: A World of Cities, eds. T Edensor and M Jayne. London: Routledge. 1-27.

Farías, I. 2010. "Introduction: decentering the object of urban studies." In Urban Assemblages: How Actor-Network Theory Changes Urban Theory, eds. I Farías and T Bender. London: Routledge. 1-24.

- 2011. The politics of urban assemblages. City 15: 365-374.

Fujita, M, P Krugman, and A J Venables. 1999. The Spatial Economy: Cities, Regions and International Trade. Cambridge, MA: MIT Press.

Fujita, M, and J-F Thisse. 2002. Economics of Agglomeration: Cities, Industrial Location, and Regional Growth. Cambridge: Cambridge University Press.

Glaeser, E.L , 2011. Triumph of the City. London: Macmillan.

Graham, S, and S Marvin. 2001. Splintering Urbanism: Networked Infrastructures, Technological Mobilities, and the Urban Condition. London: Routledge.

Habermas, J. 1971. Knowledge and Human Interests. Boston: Beacon.

Hall, P. 1998. Cities in Civilization. New York: Pantheon. 
Haraway, D. 1988. Situated knowledges. Feminist Studies 14: 575-599.

Hummels, D. 2007. Transportation costs and international trade in the second era of globalization. Journal of Economic Perspectives 21: 131-154.

Kerr, W, and S D Kominers. 2015. Agglomerative forces and cluster shapes Journal of Economics and Statistics forthcoming.

Krugman, P. 1991. Geography and Trade. Leuven, Belgium: Leuven University Press.

Kuhn, T S. 1962. The Structure of Scientific Revolutions. Chicago: University of Chicago Press.

Latour, B. 2005. Reassembling the Social: An Introduction to Actor-Network Theory. Oxford: Oxford University Press.

Lefebvre, H. 1970. La Révolution Urbaine. Paris: Gallimard.

Leitner, H, and E Sheppard. 2015. Provincializing critical urban theory: extending the ecosystem of possibilities. International Journal of Urban and Regional Research, DOI: 10.1111/1468-2427.12278

Livingstone, D. N. 2014. Dealing with Darwin: Place, Politics, and Rhetoric in Religious

Engagements with Evolution. Baltimore: Johns Hopkins University Press.

Mannheim, K. 1952. Essays in the Sociology of Knowledge. Henley-on-Thames: Routledge and Kegan Paul.

Marston, S A, J P Jones, and K Woodward. 2005. Human geography without scale. Transactions of the Institute of British Geographers 30: 416-432.

Mbembe, A, and S Nuttall. 2004. Writing the world from an African metropolis. Public Culture 16: 347-372.

McFarlane, C. 2011. Assemblage and critical urban theory. City 15: 204-224.

- 2011. Learning the City: Knowledge and Translocal Assemblage. Oxford: Wiley-Blackwell.

McFarlane, C. 2011. On context: assemblage, political economy and structure. City 15: 375-388.

Merrifield, A. 2013. The urban question under planetary capitalism. International Journal of Urban and Regional Research 37: 909-922.

Molotch, H. 1976. The city as a growth machine: the political economy of place. American Journal of Sociology 82: 309-332.

Mould, O. 2015. A limitless urban theory? A response to Scott and Storper's 'The nature of cities: the scope and limits of urban theory.' International Journal of Urban and Regional Research, DOI: 10.1111/1468-2427.12288

Mukhija, V, and A Loukaitou-Sideris. Eds. 2014. The Informal American City. Cambridge, MA: MIT Press.

Mukim, M. 2015. Coagglomeration of formal and informal industry: evidence from India. Journal of Economic Geography 15: 329-351.

Myers, G. 2014. From expected to unexpected comparisons. Singapore Journal of Tropical Geography 35: 104-118.

Ong, A, and A Roy, eds. 2011. Worlding Cities: Asian Experiments in the Art of Being Global. Oxford: Wiley-Blackwell.

Pagden, A. 2013. The Enlightenment and Why it Still Matters. New York: Random House. 
Patel, S. 2014. "Is there a 'south' perspective to urban studies?" In The Routledge Handbook on the Cities of the Global South, eds. S Parnell and S Oldfield. London: Routledge. 37-53.

Peck, J. 2015. Cities beyond compare. Regional Studies 49: 160-182.

Ren, J, and J Luger. 2015. Comparative urbanism and the Asian city: implications for research and theory. International Journal of Urban and Regional Research 39: 145-156.

Rey, P. , Y. Duroux, and C Bettelheim. 1971. Sur l'Articulation des Modes de Production. Paris: Ecole Pratique des Hautes Etudes, Centre d'Etudes de Planification Socialiste.

Robinson, J. 2006. The Ordinary City: Between Modernity and Development. London: Routledge.

- 2011. Cities in a world of cities: the comparative gesture. International Journal of Urban and Regional Research 35: 1-23.

- 2014. "New geographies of theorizing the urban: putting comparison to work for global urban studies." In The Routledge Handbook on Cities of the Global South, eds. S Parnell and S Oldfield. London: Routledge. 57-70.

Robinson, J, and A Roy. 2015. Global urbanisms and the nature of urban theory. International Journal of Urban and Regional Research, DOI: 10.1111/14682427.12272

Roweis, S T, and A J Scott. 1977. "Urban planning in theory and practice: a re-appraisal." Environment and Planning, 9, 1097-1119.

Roy, A. 2005. Urban informality: toward an epistemology of planning. Journal of the American Planning Association 71: 147-158.

. 2009. The 21st-century metropolis: new geographies of theory. Regional Studies 43: 819-830.

- 2011. Slumdog cities: rethinking subaltern urbanism. International Journal of Urban and Regional Research 35: 223-238. . 2014. Slum-free cities of the Asian century: Postcolonial government and the project of inclusive growth. Singapore Journal of Tropical Geography 35: 136150.

2015. Who is afraid of postcolonial theory? International Journal of Urban and Regional Research, DOI: 10.1111/1468-2427.12274

Said, E W. 1978. Orientalism. New York: Pantheon.

Sampson, R J. 2012. Great American City: Chicago and the Enduring Neighborhood Effect. Chicago: University of Chicago Press.

Sayer, A. 2004. "Foreward: why critical realism?" In Critical Realist applications in Organisation and Management Studies, eds. S Fleetwood and S. Ackroyd. London: Routledge. 6-20.

Scott, A J. 1980. The Urban Land Nexus and the State. London: Pion. . 2012. A World in Emergence: Cities and Regions in the 21st Century. Cheltenham: Edward Elgar.

Scott, A J, and M Storper. 2015. The nature of cities: the scope and limits of urban theory. International Journal of Urban Theory 39: 1-15.

Sheppard, E. 2014. "Globalizing capitalism and southern urbanization." In The Routledge Handbook on Cities of the Global South, eds. S Parnell and S Oldfield. London: Routledge. 
Sheppard, E, H Leitner, and A Maringanti. 2013. Provincializing global urbanism: a manifesto. Urban Geography 34: 893-900.

Simone, A. 2011. The surfacing of modern life. City 15: 355-364.

- 2014. Jakarta, Drawing the City Near. Minneapolis: University of Minnesota Press.

Smith, R G. 2013. The ordinary city trap. Environment and Planning A 45: 2290-2304.

Soja, E and A J Scott. 1986. Los Angeles: capital of the late twentieth century. Environment and Planning D: Society and Space, 4: 249-254.

Spivak, G C. 2008. "Can the subaltern speak?" In Marxism and the Interpretation of Culture, eds. C Nelson and L Grossberg. Basingstoke: Macmillan. 271-313.

Standing, G. 2011. The Precariat: The New Dangerous Class. London: Bloomsbury.

Storper, M. 2013. Keys to the City: How Economics, Institutions Social Interaction and Politics Shape Developnent. Princeton: Princeton University Press.

Taylor, P J. 2013. Extraordinary Cities: Millennia of Moral Syndromes World-Systems and City/State Relations. Cheltenham: Elgar.

Tonkiss, F. 2011. Template urbanism: four points about assemblage. City 15: 584-588.

Walker, R. 2015. Building a better theory of the urban: a response to 'Towards a New Epistemology of the Urban?'. City 19: 183-191.

Walker, R. 2016. Why cities? A response. International journal of Urban and Regional Research

Wilson, W J. 1987. The Truly Disadvantaged: The Inner City, the Underclass, and Public Policy. Chicago: University of Chicago Press.

Wirth, L. 1938. Urbanism as a way of life. American Journal of Sociology 44: 1-24. 